\title{
The Overconfidence Of Boards And The Increase In CEO Pay Over Time
}

Gregory L. Nagel, Middle Tennessee State University, USA

\begin{abstract}
This paper is based on Robert Shiller's view that hiring of external CEOs is excessive due to boards' overconfidence and causes reduced firm performance. External hire selections provide all CEOs with bargaining power. I show excessive external hiring provides an alternative explanation (excessive bargaining power) for the upward trend in CEO pay since 1945 that is largely consistent with the observed facts. A survey of the direct evidence on external hires' performance provides uniform support for Shiller's view after accounting for research supporting alternative views that only includes CEOs who survive. After adjusting for survival bias, the survey results consistently suggest that firms predominantly realize greater performance from internal promotion, all else equal. Overall, this paper's findings increase support for succession through internal executive promotion, and suggest that institutional investors can expect greater bargaining power and wealth by advocating for internal hires more often.
\end{abstract}

Keywords: CEO Pay Over Time; External vs. Internal Hire; Firm Performance; CEO Succession

\section{INTRODUCTION}

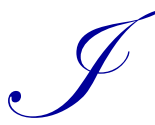

nflation adjusted CEO pay has increased nearly ten-fold since 1980 (See Figure 1). What explains this increase? There have been four primary explanations offered for the rise in CEO pay. Frydman \& Saks (2010) (hereafter FS) find that these explanations do not fit the facts over the long term.

The first explanation is offered by Gabaix \& Landier (2008), who suggest that increased firm size has led to the increase in CEO pay. However, FS find, as Figure 1 shows, that top executive pay is relatively flat from the mid1940s to the mid-1970s. During this time span firm size and profits increased considerably with no material increase in top executive pay. Second, Lustig, Syverson, \& Van Nieuwerburgh (2011) suggest that technology change explains the increase. However, FS point out that from the late1940s to the 1970s there was intense technology growth for firms in the electronics, aerospace, and chemical industries while CEO pay was relatively flat. Third, Murphy \& Zabojnik (2004) propose that the increased value of skills that can be transferred across firms (such as financial knowledge) has driven the rise in CEOs' pay. However, based on the rate of CEO pay change over the period from 1945 to 2005, FS (page 2101) observe that the increased use of transferable skills, which must be a gradual process, is not easily reconciled with the "sharp change in the trend in pay in the 1970s and the very rapid increases witnessed in the 1990s." Finally, Bebchuk \& Fried (2003) suggest that CEO pay has increased due to a breakdown in corporate governance - CEOs have used their power to extract excess pay. However, FS find little support for the explanation that CEO pay increased since 1980 due to a breakdown in corporate governance. As evidence, FS find lower levels of pay and little use of stock options, which are easier to conceal, during the 1945 to 1975 period. 


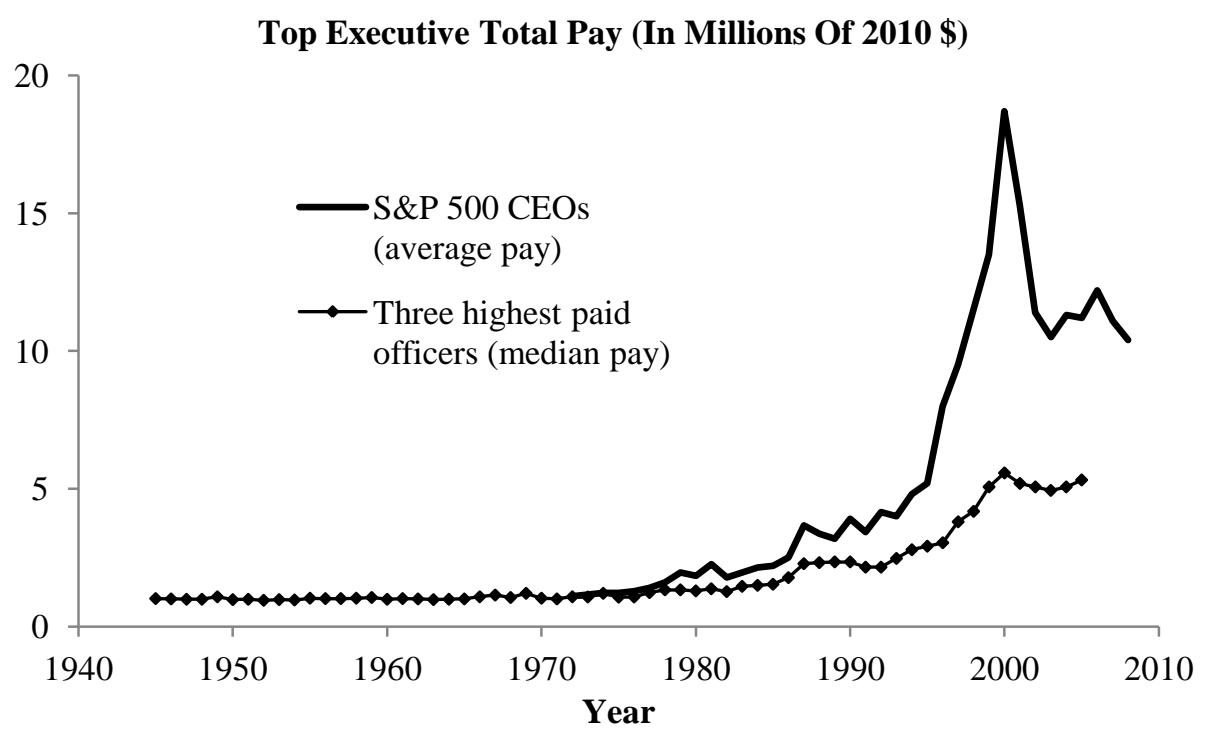

Figure 1: Top Executives Total Pay From 1945 To 2010

The S\&P 500 CEO sample is based on all CEOs included in the S\&P 500 and covers the period from 1971 to 2008. The $S \& P 500$ CEO average pay from 1971 to 1991 is obtained from Figure 1 of Jensen, Murphy, \& Wruck (2004); the S\&P 500 average pay data from 1992 to 2010 is obtained from Figure 1 of Kaplan (2013). In both cases total pay includes all cash, stock, long term pay programs, and the Black-Scholes value of stock options granted. The median pay data for the three highest paid officers (of the 50 largest firms) is obtained from Figure 1 of Frydman \& Saks (2010). Their pay information is based on the three highest paid officers in the largest fifty firms and is the sum of salary, bonus, long term bonuses, and the Black-Scholes value of stock options granted.

Overall, CEO pay increases since the 1970s do not appear to be attributable to increased firm size, increased profits, technology growth, increasingly valuable transferable skills, or a breakdown in corporate governance. These four explanations are based on CEOs' bargaining power relative to that of boards. The first three explanations assume boards hire externally to obtain greater profits, which provides all CEOs with increased bargaining power over the board. Further, these three explanations imply a relationship between pay and performance, which FS find throughout the 1945 to 2005 period. The last explanation assumes that weaker governance, with no change in CEOs' bargaining power, enables CEOs to obtain greater wages.

The purpose of this paper is to offer an explanation for the overall increase in CEO pay that fits the above facts and then point out the practical value of this alternative. First, the primary source of CEOs' bargaining power for increased pay - labor market demand - is examined. This is followed by the two opposing explanations for this demand: Robert Shiller's value destroying explanation and the value creation explanation. The plausibility of Shiller's view is discussed and examples are provided. Supporting evidence for each explanation is broadly surveyed. This survey finds the direct evidence on CEOs' performance provides uniform support for Shiller's explanation once survival bias is considered. This evidence motivates an alternative explanation for CEOs' increased pay since 1980 that fits the facts. Practical value is then pointed out for CEOs wishing to appoint an internal successor, executives, and large diversified investors.

\section{LABOR MARKET DEMAND FOR CEOs: 1945 to 2005}

Executives' ability to negotiate for greater wages primarily depends on labor market demand for one's services. Khurana (2002) (page 128) summarizes board member comments regarding executive pay determination: "How much you pay depends on how much you worry you might lose the individual." Proxy statements provide broad support for Khurana's observation; boards usually state that to retain talent, executive pay is targeted at or above the median of similar executives. Retention concerns are empirically verified. Gao, Luo, \& Tang (2013) 
shows that when a top executive is hired from a firm, many of the firm's remaining top officers quickly receive pay increases. Commonly these officers (not the sitting CEO) are the ones selected to become external CEOs (Fee \& Hadlock, 2003). Finally, Lustig et al. (2011) explicitly recognize that the external hiring of some executives provides the bargaining power for all potential participants in a labor market to negotiate for greater pay.

The evidence suggests that labor market demand for U.S. CEOs has changed over time. Prior to the 1960s the Association of Executive Search Consultants (2009) (hereafter AESC) reports there was relatively little labor market demand for U.S. CEOs. AESC reports demand for non-CEO executives began to increase in the 1970s, driven by a sharp increase in the export of goods and services. This is relevant; increased demand for top officers reporting to a CEO would increase the CEO's bargaining power. Next, search firm revenues reflect demand for external hires. The industry originated in the USA. As Figure 2.A shows, U.S. search firm revenues grew steadily starting in 1978; peaked in 2000; and revenue growth after 2004 is relatively flat (AESC suggests that the increase after 2004 is driven by international expansion of search firms). Another indicator of demand for CEOs is the external hiring rate. Murphy \& Zabojnik (2007) provide yearly data on the changing demand for external CEO hires at S\&P 500 firms from 1970 to 2005. Figure 2.B shows that the rate of external CEO hiring more than doubled in this time period from $15 \%$ to $35 \%$. Finally, Citrin \& Ogden (2010) report the average external hiring rate for S\&P 500 CEOs is $30 \%$ over the years 2004 to 2008. Overall, indicators of labor market demand for CEOs started increasing in the early 1970s, peaked in 2000, and have leveled off since 2004. Two explanations for the changing demand for CEOs since the 1940s are examined next.

Fig 2.A: Global Executive Search Revenues

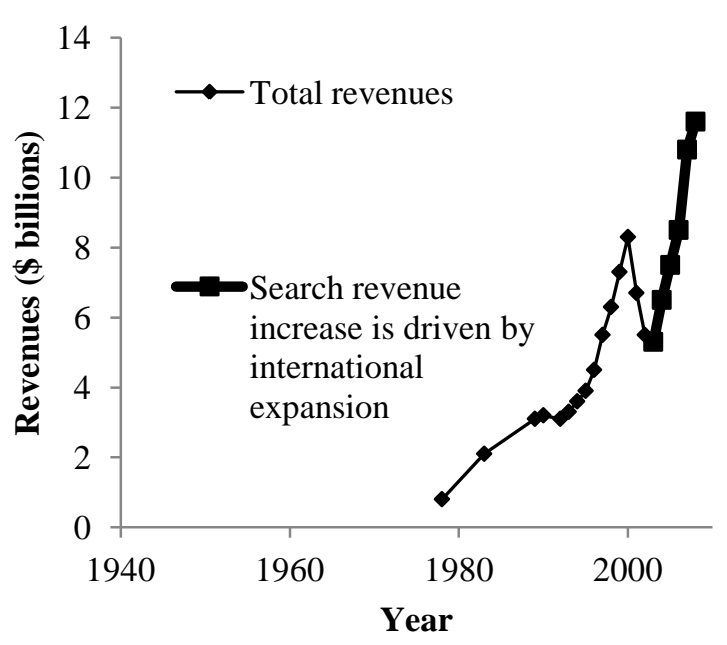

Fig 2.B: \% Of New S\&P 500 CEO Appointments That Go To Outside Hires

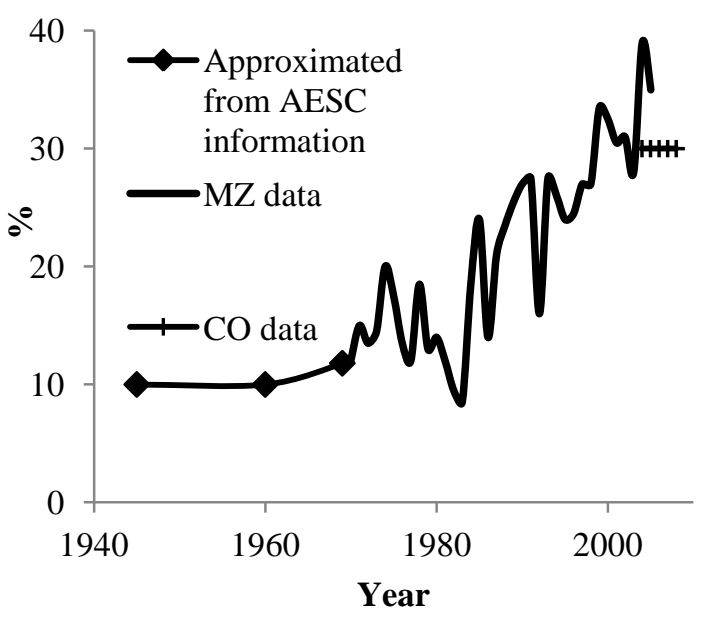

Figure 2: Indicators Of Labor Market Demand

The left hand figure (Fig 2.A) reports global search firm revenues; this information was obtained from the Association of Executive Search Consultants (2009) (Page 8). The right hand figure (Fig 2.B) reports the rate of external S\&P 500 CEO hiring from 1945 to 2008. The rate of external hiring from 1945 to 1969 is approximated based on information in Association of Executive Search Consultants (2009) (AESC). AESC reports that the rate of external hiring was minimal prior to 1960 and gradually increased in the 1960s. The external hire rate from 1970 to 2005 labeled MZ data was obtained from Figure 2 of Murphy \& Zabojnik (2007). The average external hire rate labeled CO data is reported in Citrin \& Ogden (2010); the average is for the years spanning 2004 through 2008. 


\section{TWO THEORETICAL EXPLANATIONS OF LABOR MARKET DEMAND FOR CEOs}

The first theoretical explanation for CEO labor market demand is provided by Robert Shiller. In a 2011 lecture on behavioral biases Robert Shiller, summarizing Khurana (2002), suggests that demand for external CEO hires is predominantly due to overconfidence by firms' directors: ${ }^{1}$

"This tendency for overconfidence produces a lot of anomalies ... So, for example, Rakesh Khurana, who is a professor at the Harvard Business School, has written a book called Search for the Charismatic CEO. He claims that there's a tendency for people to think that CEOs are geniuses. ... what happens, according to Khurana, is ... You bring him in to run a new company and he doesn't know anything about this new company, right? But he has to justify himself, so he lays off a lot of people and shuffles things around, and just destroys everything in the company, ..."

The result of overconfidence in hiring an external CEO is a reduction in profits, and thus a loss of shareholders' wealth. Potentially compounding the wealth loss, Khurana (2002) also finds that boards' hiring decisions are biased towards outside CEOs by their contractual arrangements with executive search firms. U.S. search firm income depends directly on the first full year cash pay of the selected candidate, and external CEOs are typically paid $30 \%$ more than inside CEOs, all else equal. ${ }^{2}$

Overconfident external hiring and agency conflicts that cause boards to hire externally will result in concerns for owners. First, excessive external hiring will increase all top executives' bargaining power for profits at owners' expense. Second, owners' of firms that hire externally for these reasons are likely to lose profits relative to what they could have had with the passed over internal CEO candidate.

An example of an overconfident external CEO hire could be Ron Johnson who was hired from Apple to become CEO of JC Penny in 2011. Bill Ackman, a hedge fund manager on JC Penny's board, recruited Ron, who then presided over a more than 50\% decrease in JC Penny's stock price. Seventeen months later (April 2013) Ron was fired. Ultimately, Myron Ullman (the previous CEO) took over from Ron Johnson.

The second theoretical explanation for CEO labor market demand is that this demand is driven by external CEOs' greater ability to generate profits, and thus wealth, relative to available internal candidates. Rosen (1981) is one of the first to propose this explanation for hiring a CEO externally. This explanation has two implications for owners. First, external hiring will increase all top executives' bargaining power for profits while increasing owners' wealth. Second, owners' of firms that hire externally to obtain more capable CEOs are likely to increase profits relative to what they could have had with the passed over internal CEO candidate.

The hiring of Louis V. Gerstner, Jr. to be CEO of International Business Machine (IBM) is a recognized example of outside talent. Louis is largely credited with turning around IBM. During his tenure from 1993 to 2002 IBM's stock price increased by more than $500 \%$.

\section{THE PLAUSIBILITY OF ROBERT SHILLER's (AND KHRUANA's) EXPLANATION}

Shiller's (and Khurana's) explanation for CEO labor market demand implies a large portion of directors reduce the value of their personal ownership position in firms, along with that of owners, by excessively hiring new CEOs externally. Is this plausible? Shiller suggests that directors "seem to have a sense that they understand the world more than they really do ... but ... they cannot think of all the perspectives at once," so, directors "think that CEOs are geniuses. Or at least the one that we found is a genius." ${ }^{3}$ This overconfidence could be reduced by experts who see multiple perspectives; however, I will soon show that experts support both explanations with extensive

\footnotetext{
${ }^{1}$ Professor Robert Shiller: Lecture 11 - Behavioral Finance and the Role of Psychology [February 21, 2011]; http://oyc.yale.edu/economics/econ252-11/lecture-11\#transcript. Shiller refers to Khurana (2002).

${ }^{2}$ The fee type for U.S. search firms was obtained from Doug Tatum, previous CEO and founder of Tatum Inc., an executive placement firm based in the USA with international operations. Zhang \& Rajagopalan (2010a) report research that finds outside CEOs obtain 30\% greater pay than inside CEOs; Bidwell (2011) finds a $20 \%$ difference below the CEO level.

${ }^{3}$ http://oyc.yale.edu/economics/econ-252-11/lecture-11\#transcript.
} 
analyses that reach opposing conclusions. This conflicted evidence informs institutional investors who influence boards, policy makers who impact boards, and reports in the press that directors may read. ${ }^{4}$ Lacking consistent expert advice, directors necessarily must rely on their own perspective in selecting the CEO. This decision is perhaps the most uncertain one that directors make (Khurana, 2002; Fernandez-Araoz, 2014). In this setting, Shiller and Khurana suggest some directors underestimate the risks involved (due to overconfidence) in hiring a relatively unknown outside CEO, and Hallock (1997) shows that a single such director can determine decision outcomes for boards.

Given their overconfidence and fiduciary duty to owners, directors naturally reach out for support to identify CEO candidates with the talent desired. Executive search firms often provide this support. As discussed above, Khurana (2002) points out that search firms are incentivized to recommend an outside hire, perhaps at owners' expense. Additionally, directors naturally seek to widen their personal networks. Contact with a search firm professional during a CEO search presents an opportunity for a director. He can market himself as a candidate for all the other positions being filled globally by the search firm. Given the unknowns and opportunities for networking, a director may choose to support the search firm's preferred outside CEO candidate recommendation.

The above discussion suggests directors could be aware of desired talents that are only obtainable from an outside CEO, but not all of the counterbalancing risks. I suggest this lack of awareness is driven by uncertainty and conflicted advice, which leads boards to become overconfident and hire externally. An example of overconfidence is seen in the JC Penny example above. As a director, Bill Ackman led JC Penny's board to hire Ron Johnson; as a result Bill's large ownership position in JC Penny dropped in value by more than 50 percent. Khurana (2002) provides additional examples of overconfidence.

\section{SURVEY OF THE PERFORMANCE EVIDENCE SUPPORTING THE TWO EXPLANATIONS OF LABOR MARKET DEMAND FOR CEOS}

Empirical analyses supporting the two views (create wealth; destroy wealth) of external CEOs' expected performance use both indirect and direct evidence. There are recognized concerns (ambiguous interpretations, spurious correlations) with inferring performance from indirect measures. For example, the rate of external CEO hiring has increased since the early 1980s. Interpretation of this evidence is ambiguous as the increase can be attributed to both expectations of superior profits, or as Robert Shiller suggests, to boards' over confidence in external hires. ${ }^{5}$ Due to these concerns I focus on research that directly measures inside and outside CEOs' performance in managing U.S. firms' assets. Though my survey is broad, ${ }^{6,7}$ the few papers offering direct evidence of inside and outside CEOs' performance are easily summarized.

\section{Direct Evidence Suggesting Labor Market Demand For External CEOs Primarily Results In A Reduction Of Firm Performance}

A line of research reports on the financial performance of internally versus externally hired CEOs using information known to boards at the time they make the hiring decision: Zajac (1990), Shen \& Cannella Jr (2002); Zhang \& Rajagopalan (2004). This research uses financial performance metrics based on firms' net income.

\footnotetext{
${ }^{4}$ Opposing academics advice is shown in my survey evidence. An example of opposing professional views are found in a comparison of Fernandez-Araoz (2014) and Citrin \& Ogden (2010).

${ }^{5}$ Stock price reactions to announcement of a new CEO also provide indirect evidence as they reflect investors' performance expectations, not outcome. In the case most likely to capture these expectations, forced turnovers, Huson, Malatesta and Parrino (2004) find investor expectations for external CEOs' performance are not realized (pages 258 and 263).

${ }^{6}$ I follow Ken Feinberg in limiting my survey to academic research. Ken Feinberg, Special Master for Executive Compensation, Treasury Department, states in his April 4, 2010, speech to the Council of Institutional Investors, "I couldn't find any independent expert consultants that were not conflicted. So we went to academia."

${ }^{7}$ The survey includes all journals on the Financial Times' list of journals they cite in the areas of management, economics, and finance: Academy of Management Journal(1963-2008); Academy of Management Perspectives (1987-2013), Academy of Management Review (1976-2008), Administrative Science Quarterly (1956-2010), California Management Review (1958-2014), Harvard Business Review (1956-2014), Human Resource Management (1961-2014), Journal of Management Studies (1997-2014), Management Science (1954-2008), Strategic Management Journal (1980-2014); American Economic Review (1911-2014), Quarterly Journal of Economics (1969-2013), RAND Journal of Economics (1984-2014); Journal of Finance (1946-2014), Journal of Financial and Quantitative Analysis (1966-2014), Journal of Financial Economics (1995-2014), and the Review of Financial Studies (1988-2014).
} 
Specifically, net income return on assets and/or return on sales are used to assess the performance of outside hired CEOs relative to inside hires. Summarizing, Zhang \& Rajagopalan (2010a) (page 457) conclude that "outside CEO successions, on average, lead to inferior post-succession performance as compared with inside successions". 8 Overall, this research suggests that boards may expect insider CEOs to outperform.

After the hiring decision is made, circumstance may arise that favor outside hires. Using information only known to boards after the new CEO is appointed, Zhang \& Rajagopalan (2010b) and Karaevli (2007) suggest that there are outcomes in which firms benefit from hiring externally. For instance, if a board was to know that a newly appointed CEO would survive at least three years and that there would be few strategic changes made, then an outside CEO on average would likely provide an advantage over inside CEOs.

\section{Direct Evidence Suggesting Labor Market Demand For Ceos Primarily Results In Improved Firm Performance}

Guthrie \& Datta (1998) and Huson, Malatesta, \& Parrino (2004) (hereafter HMP) provide direct financial evidence suggesting externally hired CEOs manage firms' assets to create wealth for owners. For this discussion I focus on HMP as their sample of CEO appointments includes that of Guthrie \& Datta (1998), is six times larger, and cover more than four times as many years. HMP (page 237) conclude that "financial performance ... is positively related to ... the appointment of an outsider (rather than an insider) CEO." Their research uses a large sample of the largest firms (Forbes 800 firms) in the U.S. economy and spans decades of CEO appointments (1971 to 1994).

The studies of HMP and Guthrie \& Datta (1998) differ from the studies discussed in the last section in two ways. First, both studies exclude the early years of CEOs tenures, when firms are most likely to incur costs from reorganizing. Reorganization is a strategy most often used by outside CEOs early in in their tenures (See Pan \& Wang, 2012). Second, both studies only include CEOs that survive many years; yet, who will survive is not known at the time of hire. Brown, Goetzmann, \& Ross (1995) show that survival bias can reverse conclusions drawn regarding expected performance. The reported results in HMP are for CEOs who survive at least three full years after the year of hire. ${ }^{9}$ Allgood \& Farrell (2003) find that external CEOs' tenures are shorter than internally promoted CEOs due to bad matches that are quickly broken between firms and these CEOs. These conditions could result in a survival bias, which HMP recognize (page 264; footnote 8). They suggest they address this bias in a robustness test. Their test examines the performance of appointed CEOs' firms, not necessarily still led by the appointed CEOs, in the third year after the appointment. This situation is illustrated in the previous description of the outside CEO appointment at JC Penny, which was followed 1.42 years later by appointment of the prior CEO. In HMP's sample, $84 \%$ of appointments are inside CEOs. Consequently HMP's approach to addressing survival bias confounds the ability of insiders appointed after a quick termination of outsiders, with the ability of these outsider CEOs. Given this potential survival bias in HMP's research and HMP's exclusion of costs for reorganization in the initial years of tenure, their conclusion is difficult to interpret.

To investigate further, Ang \& Nagel (2014) replicate the results in HMP and then minimize survival bias by using all years of a CEO's tenure. Their research also accounts for selection bias, differences in asset management ability by inside and outside CEOs, omitted variables, truncation bias, and fixed effects for firm, time, and industry. After minimizing survival bias, outside hired CEOs' operating performance is on average significantly less $(p$-value $<0.01)$ than what would have been obtained from the firms' passed over internal CEO candidates.

\section{Summary Of The Direct Evidence}

After accounting for survival bias, the direct evidence provides consistent support for Shiller's and Khurana's view that CEO external hiring predominantly detracts from owners' wealth.

\footnotetext{
${ }^{8}$ In a regression Karaevli (2007) analyzes CEO appointments in three industries and suggests that the hiring source decision has no impact on post-succession performance; however, the regression model has a negative adjusted $R$-squared. Thus, this model does not explain the data and conclusions cannot be drawn from the model.

${ }^{9}$ The results in Guthrie and Datta (1998) are for CEOs who survive approximately two full years after appointment.
} 


\section{AN ALTERNATIVE EXPLANATION FOR THE INCREASE IN CEO PAY}

After considering survival bias, the prior sections show that the direct evidence uniformly suggests that external CEO hiring predominantly reduces firms' value. Thus, from owners' perspective external CEO hiring is predominantly excessive and provides all top executives, including CEOs, with undue bargaining power when negotiating for wages and perquisites. I use this insight to explain the facts stated in the introduction.

Prior to the 1970s there was minimal search firm activity fostering demand for CEOs, and boards rarely hired CEOs externally. As a result excessive outside CEO hiring was minimized. Therefore, labor market demand for CEOs was low. Lacking bargaining power to obtain greater pay, CEOs' inflation adjusted pay remained relatively constant following World War II until the mid-1970s despite increasing firm size, increased profits, technology innovations, and relatively weak governance. Starting in the mid-1970s, increased top executive hiring began to increase CEOs' bargaining power. Starting in the mid-1980s excessive external CEO hiring progressively increased the labor market demand for CEOs. Boards' excessive external hiring provided all CEOs with undue bargaining power, which CEOs used to obtain increased pay. As in the 1945 to 1975 period, this pay was largely awarded in relation to performance, however, due to greater bargaining power, CEOs obtained more pay for the same performance. CEOs' excessive bargaining power also led to increased agency problems, as is predicted by the agency theory of Jensen \& Meckling (1976) and has been documented by Bebchuk \& Fried (2003). Excessive external CEO hiring, and so its contribution to CEOs' undue bargaining power, peaked in the mid-2000s while search firm revenues peaked in 2000, the year that CEO pay peaked. Search firm activity in the USA leveled out in the mid-2000s along with CEO external hiring. Correspondingly, CEO pay has held relatively steady since the mid2000s.

\section{CONCLUSIONS AND IMPLICATIONS FOR PRACTICE}

This study investigates an alternative explanation for the trends in CEO pay since 1945 based on Robert Shiller's observation that external hiring predominantly reduces firm value. Based on a broad survey of independent research on CEOs' performance, I find uniform support for Shiller's view after accounting for performance analyses affected by survival bias. These affected analyses presume boards only hire CEOs who will remain in office for many years and do not count any restructuring costs in the early years of tenure. My findings largely explain the major facts observed regarding U.S. CEO pay since 1945. The findings suggests that CEOs' have gained excessive bargaining power over owners, and thus more pay in relation to their performance, due to excessive external hiring.

These findings are relevant for CEO seeking to appoint an internal successor as well as executives competing with external candidates for promotion. The independent evidence presented uniformly suggests greater performance is predominantly obtained from internal CEO promotion. These results also provide support for research on the internal promotion of executives below the CEO level. Here performance cannot be directly measured, so alternative measures such as time until turnover and time until promotion are used. This literature consistently, to my knowledge, finds insiders predominantly outperform external candidates (See Bidwell, 2011; Groysberg, 2010; and Groysberg, Nanda, \& Nohria, 2004). ${ }^{10}$ Interestingly, many professionals in the executive search industry provide support for internal promotion of executives relative to external candidates. For instance, Fernandez-Araoz (2014) (page 29) suggests that external hiring is predominantly excessive from the CEO position down the line. Similar views regarding CEOs are reported by Lucier, Wheeler, \& Habbel (2007), Kwoh (2012), and Sonnenfeld, Kusin, \& Walton (2013).

Institutional investors can also gain practical insights from the finding. Excessive external hiring affects these investors' ability to bargain for cash flows, not only at firms in their portfolio that hire externally but also at the remaining firms that fear losing top executives to other firms. By advocating for internal hires more often institutional investors will gain increased control needed to monitor their investments and to set executive wages, thus enhancing owners' wealth while reducing agency problem.

\footnotetext{
${ }^{10}$ I note that all of the results, both from academics and professionals, apply to medium to large firms. Conclusion may change for small firms, where depth of talent and the time to learn new skills may be insufficient.
} 


\section{AUTHOR'S INFORMATION}

Gregory L. Nagel, Ph. D. is an Assistant Professor of Finance in the Jennings A. Jones College of Business at Middle Tennessee State University. He earned his doctorate in Finance at Florida State University. Dr. Nagel has been published in the Financial Review, Journal of Real Estate Finance and Economics, and the Quarterly Journal of Business and Economics. He is cited by search professionals such as Claudio Fernandez-Araoz and has presented to Fortune 500 size firms' heads of executive recruiting. He has also presented papers at national and international conferences. His current research interests include executive succession and institutional investors. Gregory L. Nagel, Ph.D., Middle Tennessee State University, MTSU Box 27, Murfreesboro, TN 37132, USA.

Email: Greg.Nagel@mtsu.edu

\section{ACKNOWLEDGEMENTS}

I appreciate comments by Charles Beauchamp, Michelle Beauchamp, Bruno DiGiorgi, Duane Graddy, Janisse Marblestone, and Dorothy J. Thompson.

\section{REFERENCES}

1. Allgood, S., \& Farrell, K. A. (2003). The Match between CEO and Firm. Journal of Business, 76(2), 317 341.

2. Ang, J. S., \& Nagel, G. L. (2014). The Likely Effect of CEO Hiring SOurce on Total Cash Flow Performance. Working Paper, SSRN.

3. Association of Executive Search Consultants. (2009). Executive Search at 50: A History of Retained Executive Search Consulting. Retrieved from https://members.aesc.org/eweb/DynamicPage.aspx?Site=aesc.org\&WebKey=88ff25ca-bbba-4b58-9ff7aa5de010e415.

4. Bebchuk, L. A., \& Fried, J. M. (2003). Executive Compensation as an Agency Problem. Journal of Economic Perspectives, 17(Summer), 71-92.

5. Bidwell, M. (2011). Paying More to Get Less: The Effects of External Hiring versus Internal Mobility. Administrative Science Quarterly, 56(2), 369-407.

6. Brown, S. J., Goetzmann, W. N., \& Ross, S. A. (1995). Survival. Journal of Finance, 50(3), 853-873.

7. Citrin, J. M., \& Ogden, D. (2010). Succeeding at Succession. Harvard Business Review, November, 29-31.

8. Fee, C. E., \& Hadlock, C. J. (2003). Raids, Rewards, and Reputations in the Market for Managerial Talent. The Review of Financial Studies, 16(4), 1315-1357.

9. Fernandez-Araoz, C. (2014). It's Not the How or the What but the Who: Succeed by Surrounding Yourself with the Best. Boston, Massachusetts: Harvard Business Press.

10. Frydman, C., \& Saks, R. E. (2010). Executive Compensation: A New View from a Long-Term Perspective, 1936-2005. Review of Financial Studies, 23(5), 2099-2138.

11. Gabaix, X., \& Landier, A. (2008). Why Has CEO Pay Increased So Much? Quarterly Journal of Economics, 123(1), 49-100.

12. Gao, H., Luo, J., \& Tang, T. (2013). Labor Market Competition, Executive Job-hopping, and Compensation. Working Paper, European Finance Association.

13. Groysberg, B. (2010). Chasing Stars: The Myth of Talent and the Portability of Performance. Princeton, New Jersey: Prineton University Press.

14. Groysberg, B., Nanda, A., \& Nohria, N. (2004). The Risky Business of Hiring Stars. Harvard Business Review, 82(5), 92-100.

15. Guthrie, J. P., \& Datta, D. K. (1998). Corporate Strategy, Executive Selection, and Firm Performance. Human Resource Management, 37(2), 101-111.

16. Hallock, K. F. (1997). Reciprocal interlocking boards of directors and executive compensation. Journal of Financial and Quantitative Analysis, 32, 331-344.

17. Huson, M. R., Malatesta, P. H., \& Parrino, R. (2004). Managerial Succession and Firm Performance. Journal of Financial Economics, 74(2), 237-276.

18. Jensen, M. C., \& Meckling, W. H. (1976). Theory of the firm: Managerial behavior, agency costs and ownership structure. Journal of Financial Economics, 3(4), 305-360. 
19. Jensen, M. C., Murphy, K., \& Wruck, E. G. (2004). Remuneration: Where we've been, how we got to here, what are the problems, and how to fix them. Working Paper, European Corporate Governance Institute.

20. Kaplan, S. (2013). CEO Pay and Corporate Governance in the U.S.: Perceptions, Facts, and Challenges. Journal of Applied Corporate Finance, 25(2), 8-15.

21. Karaevli, A. (2007). Performance Consequences of New CEO 'Outsiderness': Moderating Effects of Preand Post-Succession Contexts. Strategic Management Journal, 28, 681 - 706.

22. Khurana, R. (2002). Searching for a Corporate Savior: The Irrational Quest for Charismatic CEOs. Princeton, New Jersey: Princeton University Press.

23. Kwoh, L. (2012, May 30, 2012). Chief Executives Hired Internally Outlast, Outperform Their Rivals, The Wall Street Journal.

24. Lucier, C., Wheeler, S., \& Habbel, R. (2007). Era of the Inclusive Leader. Strategy+Business, Summer, 2007, 1-14.

25. Lustig, H., Syverson, C., \& Van Nieuwerburgh, S. (2011). Technology change and the growing inequality in managerial compensation. Journal of Financial Economics, 99(3), 601-627.

26. Murphy, K. J., \& Zabojnik, J. (2004). CEO Pay and Appointments: A Market-Based Explanation for Recent Trends. American Economic Review Papers and Proceedings, 94(2), 192-196.

27. Murphy, K. J., \& Zabojnik, J. (2007). Managerial Capital and the Market for CEOs. Manuscript, University of Southern California.

28. Pan, Y., \& Wang, T. Y. (2012). First Year In Office: How Do New CEOs Create Value? SSRN working paper.

29. Rosen, S. (1981). The Economics of Superstars. American Economic Review, 71, 845-858.

30. Shiller, Robert (2011). Lecture 11 - Behavioral Finance and the Role of Psychology [February 21, 2011]; http://oyc.yale.edu/economics/econ-252-11/lecture-11\#transcript. Shiller refers to Khurana (2002).

31. Shen, W., \& Cannella Jr, A. (2002). Revisiting the Performance Consequences of CEO Succession: The Impacts of Successor Type, Postsuccession Senior Executive Turnover, and Departing CEO Tenure. Academy of Management Journal, 45(4), 717-733.

32. Sonnenfeld, J., Kusin, E., \& Walton, E. (2013). What CEOs Really Think of Their Boards. Harvard Business Review, April, 2013, 98-106.

33. Zajac, E. J. (1990). CEO Selection, Succession, Compensation and Firm Performance: A Theoretical Integration and Empirical Analysis. Strategic Management Journal, 11(3), 217-230.

34. Zhang, Y., \& Rajagopalan, N. (2004). When the Known Devil Is Better Than an Unknown God: An Empirical Study of the Antecedents and Consequences of Relay CEO Successions. Academy of Management Journal, 47(4), 483-500.

35. Zhang, Y., \& Rajagopalan, N. (2010a). CEO succession planning: Finally at the center stage of the boardroom. Business Horizons, 53, 455- 462.

36. Zhang, Y., \& Rajagopalan, N. (2010b). Once an Outsider, Always an Outsider? CEO Origin, Strategic Change, and Firm Performance. Strategic Management Journal, 31, 334-346. 


\section{NOTES}

